\title{
Problemy współczesnego dualnego kształcenia zawodowego w Niemczech. Między dynamiką zmian a wielokulturowością
}

\begin{abstract}
Streszczenie
System dualnego kształcenia zawodowego w Niemczech jest uznawany za wzór na świecie. Druga dekada XXI wieku upływa w świetle widocznych skutków rewolucji technologicznej, zmian społecznych i nasilonych ruchów migracyjnych. Trudności w obsadzaniu miejsc nauki, potrzeba intensyfikacji orientacji zawodowej, zacieśnienie współpracy ze szkołami wpływają na formowanie nowych rozwiązań wewnątrz systemu. W kontekście polskiej reformy kształcenia zawodowego nowego znaczenia nabierają takie paradygmaty, jak pracodawca i szkoła, uczeń i mistrz, orientacja zawodowa, integracja zawodowa migrantów. Bieżące wyzwania dualnego systemu w Niemczech i sposoby rozwiązań stają się impulsem do aktualnej dyskusji o kształceniu zawodowym młodzieży w Polsce.
\end{abstract}

\section{Słowa kluczowe:}

system dualny kształcenia, niemiecki model edukacji zawodowej, nowe technologie, digitalizacja, migracja, wielokulturowość

\section{Abstract}

The dual vocational education system in Germany is recognised as a model worldwide. The second decade of the 21st century is unfolding under the

1 Anna Karolina Rogowska, WOLFF \& MÜLLER Holding GmbH \& Co. KG w Stuttgarcie, Szkoła Polska przy Konsulacie Generalnym Rzeczypospolitej Polskiej w Monachium z siedzibą w Remseck, Niemcy, e-mail: arogowsk@gmail.com, ORCID ID: https://orcid.org/0000-0001-7708-8790. 
visible effects of the technological revolution, social changes and intensified migration flows. Difficulties in filling vacant working places, the need to intensify professional orientation, closer cooperation among schools influence the development of new solutions for the system. In relation to the Polish vocational education reform, such paradigms as employer and school, student and master, vocational orientation, professional integration of migrants acquire new meanings. The current problems of the German dual system and its possible solutions become a reference for the current discussion on young people's vocational education in Poland.

\section{Keywords:}

dual education system, German vocational education model, new technology, digitalisation, migration, multiculturalism

\section{WSTĘP}

Jeśli historia jest matką nauk, jak powiadał Cyceron, to uczenie się na błędach przeszłości jest naszą powinnością². Wielokrotnie w dziejach ludzkości okazywało się, że dzisiejsze rozwiązania są pochodną czyjegoś pomysłu lub nauką wynikającą z popełnionych błędów. W takim razie uczenie się jest koniecznością w każdym czasie i w każdej sytuacji.

Zdaniem Robinsona zainteresowanie kształceniem wynika z tego, że edukacja jest czymś, co ma nas przenieść do przyszłości, której w tej chwili nie jesteśmy w stanie przewidzieć ${ }^{3}$. Nikt nie wie, jak będzie wyglądał świat za kilka lat. Sądzimy jednak, iż potrafimy przygotować nowe pokolenia na to, co nadejdzie w przyszłości.

Z tą myślą podejmujemy się działań w procesie nauczania. W Europie kształcenie jest zdeterminowane długoletnią tradycją. W Niemczech kształcenie zawodowe jest zakorzenione w przeszłości. Sytem rozwinął i upowszechnił się przed europejską rewolucją przemysłową, ugruntował się w XX wieku, a apogeum osiągnął we współczesności.

Obecnie jest konstrukcją elastycznie reagującą na potrzeby zmian zorientowanych na przyszłość. Przy tym z poszanowaniem tradycji nakierowany jest na nowoczesność. Dawne niemieckie zrzeszenia cech rzemiosł przedprzemysłowych

2 Marek Tuliusz Cyceron (łac. Marcus Tullius Cicero), Historia magistra vitea (est), De oratore, II 36, 55 p.n.e.

${ }^{3}$ Ken Robinson, Do schools kill creativity, Wykład na Konferencji TED Talk, Montrey, Kalifornia 2006, szerzej na ten temat zob. https://tiny.pl/7w9wq [dostęp: 9.03.2020]. 
były sprawdzoną szkołą przygotowania zawodowego. Od wieków przyjmowano uczniów na naukę do warsztatów. W rodzinach mistrzów młodzież zdobywała szacunek do rzemiosła. Ten rodzaj wychowania zawodowego miał wpływ na modelowanie charakterów i rozwój zamiłowań (Stratmann, 1993, s. 5). Dawni mistrzowie byli niczym ojcowie; sprawowali funkcje opiekuńcze. Dziś wielu fachowców ma pod opieką w zakładach pracy uczniów kształcących się w zawodzie. Z chwilą wprowadzenia w Niemczech ustawy o kształceniu zawodowym system ten został normatywnie nastawiony na potrzeby rynku pracy ${ }^{4}$.

Z tej perspektywy podejmowane rozważania o wyzwaniach wobec współczesnego dualnego systemu w Niemczech mogą utwierdzić nas w przekonaniu, że edukacja zawodowa naszych sąsiadów zza Odry, Łaby i Renu opiera się na doświadczeniach, próbach i błędach. Przy tym zawsze odnosi się do realiów wolnego rynku. Przeciwności, na które napotykał w swojej historii system dualny w Niemczech, nie były i nie są czymś nowym. Obserwując jednak dynamikę zmian społecznych i technologicznych sprzężonych z gospodarczymi uwarunkowaniami, szczególnie w ostatnim pięcioleciu, warto zwrócić uwagę na nowe tendencje w tej dziedzinie.

Zamierzeniem opracowania jest zwrócenie uwagi na wybrane, aktualne i ważne problemy systemu dualnego w Niemczech. Ich wartość edukacyjna widoczna będzie dopiero w przyszłości. Jednak już dziś można obserwować wpływy, którym poddawany jest system, szczególnie w zakresie dynamiki zmian i wielokulturowości.

Od dawna przemiany demograficzne i technologiczne wyznaczały kierunki rozwoju systemu kształcenia. Podejmowane w Niemczech dyskusje o systemie edukacji zawodowej 4.0 nabierają intensywnego wymiaru 5 . Organizowane są fora dyskusyjne z udziałem przedstawicieli nauki, polityki, przemysłu i rzemiosła. Dofinansowywaniu podlegają projekty wdrażające transformację digitalną ${ }^{6}$. Cyfryzacja świata pracy ma swoje nieuchronne odzwierciedlenie w funkcjonowaniu dualnego systemu.

Wiadomo, że multikulturalizm nigdy nie był oficjalną stroną polityki rządu niemieckiego. Co więcej, nie budził uznania społeczeństwa (Rattansi, 2011, s. 36).

4 Ustawą o kształceniu zawodowym (1969) wprowadzono nowy podmiot odpowiedzialny za dualny system kształcenia, którym jest przedsiębiorstwo, szerzej na ten temat zob. http://www. gesetze-im-internet.de/bbig_2005/ [dostęp: 10.03.2020].

5 Pojęcie systemu kształcenia zawodowego 4.0 („Ausbildung 4.0”) wywodzi się od określenia czwartej rewolucji przemysłowej 4.0 („Industrie 4.0”).

${ }^{6}$ Forum Ausbildung 4.0 digital-vernetzt zukunftsfähig, Stuttgart, 3.03.2020, pobrane z: https:// tiny.pl/7w9wg [dostęp: 10.03.2020]. 
Jednak na skutek imigracji zarobkowej do Niemiec kraj ten stał się de facto wielokulturowy (Kraus, Schönwälder, 2006, s. 210). W roku 2018 w Niemczech zamieszkiwało prawie 20,8 mln osób z tłem migracyjnym, co stanowi 25,5\% ludności z przyrostem w stosunku do roku 2017 aż o 2,5\%․ Fale migracyjne, a zwłaszcza ostatnia w roku 2015, miały wymierny wpływ na dualny system kształcenia w Niemczech ${ }^{8}$. Udział osób z pochodzeniem migracyjnym uczących się w niemieckim systemie zawodowym jest obecnie wysoki. Systematycznie dokonuje się adaptacji cudzoziemców w procesie kształcenia zawodowego, i to z pożytkiem obu stron: państwa i emigrantów. Z tej perspektywy wartościowe wydają się poczynania rządu, przedsiębiorstw, szkół i izb przemysłowo-handlowych. Zdaniem Kabaja, obok tradycji, to motywacja partnerów procesu edukacyjnego jest głównym determinantem wdrożenia i funkcjonowania systemu dualnego (Kabaj, 2012, s. 85).

W świetle aktualnej polskiej reformy edukacji zawodowej oraz dyskusji toczących się wokół problematyki kształcenia zawodowego w Polsce warto zaczerpnąć z historii i doświadczeń niemieckich. Pamiętać trzeba, że zwrócenie się ku sprzężeniu edukacji zawodowej z prawem podaży i popytu musi opierać się na zaangażowaniu przedsiębiorstw, szkół, ośrodków szkoleniowych i monitorujących proces izb przemysłowo-handlowych. To taka relacja i taka kolejność graczy zapewnia wysoką jakość kształcenia zawodowego, ściśle dopasowanego do potrzeb rynku. Ma też wpływ na jakość życia ludzi uczących się i rozwijających się w pracy przez całe życie.

\section{NIEMIECKI SYSTEM DUALNY WZOREM EDUKACJI ZAWODOWEJ}

Dualny system kształcenia stanowi w Niemczech główną ścieżkę przyuczenia do zawodu (Chatzichristou, Ulicna, Murphy, Curth, 2014, s. 3). Jednocześnie wychodzi się z założenia, że proces nauki trwa nieskończenie. Każdy pracownik uczy się w swoim zakładzie, dopóki jest w nim zatrudniony. Niemieckie określenie tego systemu, „Berufsausbildung”, utożsamiane jest w społeczeństwie z marką kształcenia. Słowo to jest znakiem rozpoznawczym, oznaczającym solidność i praktyczność edukacji zawodowej. Dostęp do systemu mają wszyscy, niezależnie

7 Bevölkerung in Privathaushalten nach Migrationshintergrund. Statistisches Bundesamt (Destatis), 21.08.2019, pobrane z: https://tiny.pl/7w9w7 [dostęp: 21.03.2020].

8 Napływ uchodźców i migrantów do Europy w 2015 roku spowodował kryzys migracyjny. Dla Niemiec fala migracyjna w roku 2015 stanowiła wyzwanie polityczno-społeczne (tu: również szansę w obliczu starzejącego się społeczeństwa i rosnącego deficytu wykwalifikowanej siły roboczej). 
od tego, czy ukończyli w Niemczech szkołę podstawową, szkołę główną, czy zdali maturę. System dopuszcza też możliwość rozpoczęcia edukacji bez ukończenia szkoły. Interesująca w ostatnim dziesięcioleciu jest dopuszczalność systemu dla różnych grup wiekowych. Mimo iż średnia wieku przyszłych adeptów zawodu wynosi 19,7, to coraz częściej przyjmowane są osoby powyżej 40. roku życia (M. Friedrich, 2019, s. 181). Zatem doświadczenia życiowe i zawodowe osób dorosłych to także doceniany element w kształceniu.

Ponadto niemiecki system kształcenia zawodowego przewiduje możliwości rozwoju również bez ukończenia studiów. Atrakcyjność kształcenia wynika z tego, że nie zamyka szans na dalszą edukację. To właśnie aspekt drożności zalicza Kabaj do głównego wyznacznika popularności kształcenia w wysoko rozwiniętych krajach europejskich (Kabaj, 2016, s. 19).

Ten unikalny system jest popierany w niemieckich kręgach rzemieślniczych oraz przemysłowych tak bardzo, iż cechy rzemiosł i związki branżowe rozpowszechniają wiedzę na temat zawodów wśród uczniów, rodziców i przedsiębiorstw. Prowadzą działalność badawczą, wspierają przedsiębiorstwa i szkoły, łączą się w gremia i tworzą lobby branżowe do zmian prawnych.

Niemcy są dumni z tego systemu, bo w nim wyraźnie zintegrowany został paradygmat uczeń - mistrz, który kształtuje pojęcie tożsamości zawodowej (Stępnikowski, 2016, s. 37). Pamiętajmy jednak, że solidne podstawy tego systemu są zbudowane nie tylko przez tradycję. To działalność wielu wolontariuszy przyczynia się do sukcesów. Ten ostatni aspekt w wielu branżach potwierdza rangę systemu. Nie bez przyczyny Komisja Europejska zaleca jego stosowanie (Kabaj, 2012, s. 84). „(...) System edukacji krajów Unii Europejskiej musi zbliżyć się do potrzeb gospodarki przez rozszerzenie kształcenia dualnego (a best practice example) (...)” (European Commission 1994, s. 133-137).

Warto dodać, że w państwie o nowoczesnej gospodarce przemysłowej dualny system sprawia, że kraj ten stosunkowo dobrze radzi sobie z problematyką bezrobocia wśród młodzieży (Fritsch, 2013, s. 1). Wpływ systemu kształcenia jest nieodzownie sprzężony ze wskaźnikiem bezrobocia młodych ludzi.

Niemcy od lat wiodą prym w europejskiej czołówce krajów o najniższej stopie bezrobocia młodzieży i przewadze kształcenia dualnego. W wielkiej piątce tuż za naszymi zachodnimi sąsiadami są: Szwajcaria, Austria, Holandia i Dania (Kabaj, 2012, s. 16). Filarami systemu niemieckiego jest nauka w rzeczywistych warunkach pracy i w rzeczywistym środowisku w przedsiębiorstwach oraz krótki czas poszukiwania pracy przez absolwentów. Przekłada się to na zatrudnienie młodzieży, poziom gospodarczy kraju, a nade wszystko satysfakcję młodych ludzi. Czują się oni potrzebni, dostrzegają swoje perspektywy zawodowe, są aktywni, 
bo doceniani. „Dlatego też system dualny jest obecnie jednym ze szlagierów eksportowych Niemiec. Duży popyt na niemieckie doświadczenia odnotować można nie tylko w Europie, lecz także w Stanach Zjednoczonych i w Azji” (Fritsch, 2013, s. 1).

\section{SYSTEM DUALNY NIE TYLKO DLA NIEMCÓW}

Czynniki globalne, a zwłaszcza ruchy migracyjne oraz zaawansowane technologie, wpływają na kształcenie zawodowe w świecie. Każdy krajowy system edukacji zawodowej musi być z jednej strony elastyczny, z drugiej zaś zapewniać odpowiednie standardy. Wobec wyzwań gospodarczych i społecznych firmy poszukują sposobów na zapewnienie sobie zasobów ludzkich o odpowiednich umiejętnościach (Stępnikowski, 2016, s. 36).

Dualny system kształcenia w Niemczech stał się odpowiedzią na potrzeby pracodawców pozyskania pracownika o wysokim przygotowaniu jakościowym i holistycznych cechach w zawodzie. Z drugiej zaś strony daje on konkretne odpowiedzi w kontekście integracji społeczno-zawodowej osób z pochodzeniem migracyjnym. Problematyka fal migracyjnych, która w niektórych krajach pojmowana jest w obszarze barier, została nad Odrą, Łabą i Renem wykorzystana w kontekście szansy dla rynku pracy.

Kluczową rolę w integracji migrantów należy przypisać sektorowi przedsiębiorstw, które prowadzą rekrutację i decydują o przyjęciu kandydatów do systemu dualnego. Rośnie liczba przedsiębiorstw zainteresowanych kształceniem migrantów. Poszerza się też skala narodowości osób przyjmowanych do nauki i pracy (Wegner, 2019, s. 3).

Aż 40\% niemieckich przedsiębiorstw objęło w roku 2018 dualnym kształceniem uczniów z pochodzeniem migracyjnym. Odsetek zakładów kształcących cudzoziemców z Unii Europejskiej stanowiło zaledwie 11\%. Aż 15\% tychże firm w Niemczech kształciło wyłącznie osoby z pochodzeniem pozaunijnym, głównie z krajów Trzeciego Świata (Wegner, 2019, s. 1). Najliczniej reprezentowane były dotąd Turcja (22 905), Afganistan (13 371) i Syria (12 762) (Bildung und Kultur, 2018, s. 24). Porównując wskaźnik Polaków kształcących się w niemieckim systemie dualnym, który w roku 2018 wynosił 4707 uczniów, można przyjąć, iż grupa rodaków kształcących się w tym systemie należy do mniejszości. Wyniki badań Niemieckiej Izby Przemysłowo-Handlowej z dnia 11 sierpnia 2019 roku obejmujące opinie przedsiębiorstw w zakresie problematyki dualnego systemu kształcenia zawodowego za rok 2018 wskazują, iż dalsze 15\% przedsiębiorstw 
przyjęło w systemie dualnym zarówno uczniów z Unii Europejskiej, jak i z krajów Trzeciego Świata (U. Friedrich, 2019). W roku 2018 naukę w systemie dualnego kształcenia zawodowego podjęło w Niemczech łącznie 521901 osób (stan na sierpień 2018) (Bildung und Kultur, 2018, s. 35). Aż 61032 nowych uczniów miało pochodzenie migracyjne. Liczba ta podwoiła się w stosunku do roku 2009. Udział przyszłych adeptów zawodów rośnie w dynamicznym tempie. Najwięcej jest ich w przedsiębiorstwach małych i średnich. Intensywnie rozwijającą się grupę - tak jak wspomniano - stanowią w ostatnim pięcioleciu uchodźcy. Dla nich system niemieckiego kształcenia dualnego proponuje bodźce przyspieszające integrację o charakterze przygotowawczym i wspierającym. Nadrzędną rolę pełnią kursy językowe.

Modernizacja niemieckiego systemu dualnego kształcenia w połączeniu z rozwojem elastycznych organizacji form pracy jest jednym z kamieni milowych procesu umocnienia się gospodarki niemieckiej od lat 90. XX wieku. Partnerzy systemu, zarówno ze strony społeczeństwa, gospodarki, jak i polityki, traktują kwestie zapewnienia wystarczającej liczby miejsc przyuczenia zawodowego na rynku pracy jako swój istotny obowiązek. I dzięki temu młodzież nie była w przeszłości - jak to miało miejsce w innych krajach - porzucona na margines ponoszący ciężar kryzysów (Bosch, 2018, s. 5). To właśnie systemowe podejście do problematyki oraz społeczne postrzeganie przygotowania zawodowego stanowi o możliwości kształcenia w kontekście wielokulturowym.

\section{TRANSFORMACJA PROCESU REKRUTACJI W SYSTEMIE DUALNYM}

W ostatnim dziesięcioleciu obserwuje się trudności w obsadzaniu miejsc nauki w przedsiębiorstwach. Pracodawca jako kluczowy partner decyduje o liczbie oraz rodzaju ofert. W ten sposób organizacja pracy odpowiada nie tylko za jakościowe przygotowanie w ciągu czasu trwania nauki, ale koordynuje struktury i treści kształcenia z popytem na pracę (Kabaj, 2016, s. 16).

Rozwój rynku dualnego kształcenia zawodowego w Niemczech odnotował w roku 2018 najwyższy wskaźnik ofert w przedsiębiorstwach w ostatnim dziesięcioleciu. Przyszli adepci zawodów mieli do dyspozycji aż 574185 miejsc nauki w zakładach usługowych i produkcyjnych (M. Friedrich, 2019, s. 23). Było to najwięcej od roku 2009. Niestety ta chlubna oferta pracodawców zderzyła się z rzeczywistością rosnącego wskaźnika miejsc nieobsadzonych, który w roku 2018 był trzykrotnie wyższy niż w roku 2009. Liczba wolnych miejsc nauki wyniosła aż 57 656, co w porównaniu z rokiem 2009 z ówczesną liczbą wolnych stanowisk 
17766 potwierdza dobre tendencje rynku kształcenia dualnego. Statystycznie ujmując, jeszcze nigdy w ostatnim dziesięcioleciu szanse kandydatów na znalezienie miejsca nauki w systemie dualnym w Niemczech nie były tak dobre jak w roku 2018. Na 100 osób chętnych przypadało aż 96,6 ofert. Mimo bogatej oferty i przy umiarkowanym wzroście zawartych nowych umów o kształcenie w dualnym systemie o 1,6\% (ponad 52 000) liczba osób bez miejsc nauki wynosiła 78619 (mniej o 1600 niż w 2017 roku).

Jak pisałam, w ostatnim dziesięcioleciu systematycznemu zwiększaniu się liczby ofert pracodawców i wzrostowi liczby nieobsadzonych miejsc nauki towarzyszy zmniejszająca się ogólna liczba osób pozostających bez miejsc nauki. Tendencja ta nadal się utrzymuje. We wrześniu 2019 roku aż 60000 miejsc nauki pozostało nieobsadzonych (Bundesagentur für Arbeit, Statistik, 2019). Według tymczasowych danych Krajowego Urzędu Statystycznego aktualna liczba podpisanych umów w roku 2019 zmiejszyła się o 1,4\% w stosunku do roku 2018 (Bundesagentur für Arbeit, Statistik, 2019). Wskazuje to na fakt, iż mimo nieustannego zaangażowania pracodawców i popytu gospodarki na konkretne kwalifikacje w przyszłości oraz statystycznie dużych szans na znalezienie miejsca nauki pojawiają się problemy. Chodzi o dopasowanie profili wymagań oferentów z oczekiwaniami i możliwościami kandydatów.

Przyczyn tego zjawiska upatruje się głównie w poziomie ukończonej szkoły przez kandydatów. Coraz więcej uczniów zainteresowanych uzyskaniem miejsca nauki w systemie dualnym legitymuje się ukończeniem szkoły kwalifikującej do podjęcia studiów. To z kolei przekłada się na zakres zainteresowania w zawodach pozarzemieślniczych i spadek zainteresowania zawodami tradycyjnymi, które dotąd wybierali uczniowie kończący szkołę nieuprawniającą do podjęcia studiów (Sponholz, Ulrich, 2019). Sytuacje te ilustrują wskaźniki korelacji między podażą ofert w systemie dualnym a popytem na nie w roku 2018 w poszczególnych zawodach (M. Friedrich, 2019, s. 23). Niskim wskaźnikiem korelacji cechują się zawody takie jak media dźwięku i obrazu, fotografia. W tych zawodach chętni muszą kwalifikować się wyższymi kompetencjami wyjściowymi, co wymaga ukończenia szkoły na wyższym poziomie. Ponieważ rynek jest tutaj przesycony kandydatami spełniającymi wymagania wstępne, liczba miejsc nieobsadzonych jest mniejsza, lecz akceptowalna. Równie wysoka jest liczba osób pozostających bez miejsca nauki. W tej grupie kandydaci z tradycyjnym dla systemu poziomem ukończonej szkoły głównej (niższym), w przypadku zainteresowania, pozostają bez zamierzonego miejsca nauki. Dzieje się tak z uwagi na niespełnienie wymagań wstępnych. W odróżnieniu od tej grupy, oferenci zawodów wymagających klasycznego poziomu ukończenia szkoły 
głównej, takich jak piekarz, sprzedawca, borykają się z problemami obsadzenia miejsc nauki. Tu wskaźniki korelacji szacowane są dla roku 2018 w wysokich granicach między 114 a 159. Liczba miejsc przewyższa liczbę chętnych do nauki, również z uwagi na zainteresowanie tymi zawodami osób bez ukończonej szkoły. Obserwacje czynione do tej pory wskazują na fakt, iż bez miejsc nauki pozostają uczniowie bez ukończonej szkoły lub o niskim poziomie wykształcenia. Dlaczego więc w roku 2018 prawie dwie trzecie osób pozostało bez miejsca nauki, choć legitymowało się ukończeniem szkoły realnej lub świadectwem dojrzałości? Złożyło się na to wiele czynników.

Nie bez znaczenia pozostaje demografia. Dodatkowo w północnych Niemczech system dotyka w roku 2020 konsekwencja przestawienia z ośmioletniego na dziewięcioletnie gimnazjum maturalne. Efektem jest brak maturzystów w tym roku szkolnym.

Interesująca, z uwagi na obsadzanie miejsc nauki w systemie dualnym, jest liczba studentów przerywających studia. Wskaźnik ten rośnie proporcjonalnie do przyrostu studiujących. Stąd programy mające na celu umożliwić przedsiębiorstwom i szkołom zawodowym przyjęcie byłych studentów do kształcenia zawodu w systemie dualnym.

W kontekście dynamiki zmian wewnątrz poszczególnych branż postęp w stosunku do lat ubiegłych obserwuje się w obsadzaniu stanowisk w przemyśle budowlanym i opiece zdrowotnej. Obie branże zarejestrowały poprawę w stosunku do roku 2017 (U. Friedrich, 2019, s. 7).

I to, co istotne, wielokulturowość okazała się w Republice Federalnej Niemiec daleko pojętą szansą. W gastronomii, budownictwie i transporcie znaleźli możliwości kształcenia obcokrajowcy. Otworzyły się dla nich małe i średnie przedsiębiorstwa borykające się z niedoborem chętnych do nauki. Nie lada wyzwaniem stała się próba włączenia do systemu dualnego osób o odmiennej kulturze, języku i z brakiem porównywalnych doświadczeń, słabo znających realia życia w kraju.

Z perspektywy czterech lat doświadczeń okazuje się, że powodzenie tych działań było przeceniane. Niemniej jednak obserwuje się wzrost przyjęć do systemu dualnego osób z fali migracyjnej 2015 roku pochodzących z krajów trzecich. W roku 2019 Izba Przemysłowo-Handlowa zarejestrowała aż 16\% zakładów kształcących tę grupę osób, w roku 2018: 14\%, natomiast w roku 2017: 7\%. Problemem przy obsadzaniu stanowisk był brak realnego wyobrażenia kandydatów o zawodach, nieporównywalność ich dotychczasowych doświadczeń zawodowych w krajach macierzystych, odmienne uwarunkowania kulturalne, niski poziom dotychczasowego wykształcenia, brak lub słaba znajomość języka niemieckiego, brak znajomości alfabetu łacińskiego. Punktem krytycznym stały się nieznajomość 
języka kraju oraz brak umiejętności zapisu znaków rzymskich. Pracodawcy stanęli zatem przed niemałym wyzwaniem.

Rozwiązaniem okazała się adaptacja kursów przygotowawczych do rozpoczęcia nauki w systemie dualnym („Einstiegsqualifizierung”"), uruchomienie instytucji pomocowych w trakcie trwania kształcenia dualnego, również dla migrantów („Assistierte Ausbildung”"10, „Ausbildungsbegleitende Hilfen”"11), a nade wszystko kursów językowych dla uchodźców. Kandydatów nakłania się do zdania egzaminu językowego przed rozpoczęciem kształcenia zawodowego. Wykorzystując motywację migrantów, niektórzy pracodawcy uzależnili uzyskanie miejsca w systemie dualnym od pozytywnego zdania egzaminu językowego. Należy wspomnieć, iż wprowadzona w 2016 roku zasada „3+2” umożliwiła uchodźcom bez prawa pobytu kontynuację nauki i zatrudnienie w zawodzie przez dwa lata po jej ukończeniu (Gesetz über den Aufenthalt, die Erwerbsfähigkeit und die Integration von Ausländern im Bundesgebiet, Art. 60c). Nauka zawodu nabrała w ten sposób egzystencjalnego znaczenia. Integracja wsparta została kursami kulturalnymi i doradztwem zawodowym, co w efekcie wydłużyło czas kształcenia. Grupa ta z uwagi na specyfikę potrzeb, odmiennych od uczniów niemieckich lub migrantów osadzonych w realiach kraju, wymaga innej opieki wykraczającej poza przyjęte standardy. Możliwe jest to przy współpracy szkół, pracodawców, izb i lokalnych władz. Współpraca partnerów dualnych nabrała w tym aspekcie w ostatnich pięciu latach nowych, niespotykanych dotąd wymiarów.

W sytuacjach, gdy pojawiają się trudności w obsadzaniu miejsc nauki, Izba Przemysłowo-Handlowa prowadzi wymianę doświadczeń z pracodawcami. Prowadzone są kampanie reklamowe, organizowane są sympozja mające na celu zapoznanie się zainteresowanych uczniów z zawodami. Szczególnym zaangażowaniem stron cieszą się akcje skierowane do grup słabo reprezentowanych w systemie, na przykład dziewcząt w zawodach technicznych ${ }^{12}$. Z drugiej strony izby prowadzą dla swoich członków doradztwo w zakresie nowoczesnych form wzbudzenia

${ }^{9}$ W skrócie EQ, program wyrównawczy dla kandydatów nauki zawodu o charakterze orientacji zawodowej realizowany przed podjęciem nauki w systemie dualnym, szerzej na ten temat zob. https:// tiny.pl/7w9dd [dostęp: 22.03.2020].

${ }^{10}$ W skrócie AsA, program pomocy w trakcie trwania nauki zawodu, włącza dodatkowe wsparcie dla ucznia, zgodnie z jego potrzebami: pedagoga, psychologa, pracownika społecznego, wychowawcę, szerzej na ten temat zob. https://tiny.pl/7w9ww [dostęp: 22.03.2020].

11 W skrócie abH, program pomocy w trakcie nauki zawodu obejmuje korepetycje, zajęcia wyrównawcze przedmiotowe lub językowe, szerzej na ten temat zob. https://tiny.pl/7w9df [dostęp: 22.03.2020].

12 Szerzej na ten temat zob. https://www.girls-day.de/, https://www.boys-day.de/ [dostęp: 29.03.2020]. 
zainteresowania danymi zawodami wśród pokolenia $\mathrm{Z}^{13}$. Tu nieodłączne staje się zastosowanie najnowszych technologii, które muszą znaleźć przełożenie w ofercie nauki zawodu. Potrzeby konkretnych branż i w konkretnych regionach zaowocowały uruchomieniem specjalnych programów, na przykład „Start do zawodu w budownictwie” w Saksonii ${ }^{14}$. Dzięki temu programowi w roku 2018 udało się zatrzymać dramatyczny spadek kandydatów o 8,6\% (Kraus, Weitz, 2020, s. 23). Szkoły i pracodawcy, którzy dokonają transformacji w zakresie sposobu pozyskiwania kandydatów, uwzględniając potrzeby młodego pokolenia, niezależnie od pochodzenia migracyjnego, mogą rekrutować efektywniej.

\section{WIĘCEJ ZAANGAŻOWANIA W ORIENTACJI ZAWODOWEJ}

Badanie Niemieckiej Izby Przemysłowo-Handlowej wykazało, że prawie połowa pracodawców za pilną potrzebę uznaje zwiększenie wyobrażeń o zawodach (U. Friedrich, 2019, s. 3). Coraz więcej uczniów nie ma wiedzy o przyszłej profesji. Jest to problem, który prowadzi do spowolnienia procesu nauczania. Pracodawcy muszą najpierw poświęcić uwagę synchronizacji wzajemnych wyobrażeń i oczekiwań obu stron. Zjawisko to może doprowadzić do przerwania nauki przez ucznia.

Nie jest tajemnicą, że rośnie odsetek uczniów przerywających naukę zawodu. W roku 2018 łącznie odeszła z systemu jedna czwarta uczniów. Wysokie dane notuje się wśród grupy osób migracyjnych. Rok 2018 przyniósł wysoki wskaźnik: 35\% przyszłych adeptów o pochodzeniu migracyjnym przerwało naukę (Statistisches Bundesamt (Destatis), 2019). Warto mieć na uwadze, że orientacja zawodowa jest kluczowym uwarunkowaniem sprawnej i zakończonej sukcesem nauki zawodu. Przyszli uczniowie muszą z wyprzedzeniem poznać ogólną specyfikę zawodu, możliwości zatrudnienia, wynagrodzenia, szanse rozwoju. Jak wiadomo, uczniowie uczący się poza systemem oświatowym muszą zdobyć konkretne umiejętności w krótszym okresie niż uczniowie podejmujący naukę w dłuższych cyklach kształcenia. „(...) Ich edukacja nie pozostawia wielu szans na "próbowanie« ról osób dorosłych, stają się dorosłymi szybko, podejmując role zawodowe (...)” (Piorunek, 2016, s. 5).

13 Pokolenie Z (ang. generation Z), ludzie urodzeni w drugiej połowie lat 90. XX wieku i po 2000 roku, wkraczający na rynek pracy, dorastający w świecie nowoczesnych technologii, cechujący się doskonałą ich znajomością.

14 Szerzej na ten temat zob. https://www.bau-bildung.de/ausbildung-studium/berufsstart-bau/ [dostęp: 26.04.2020]. 
Doskonale zbudowana platforma niemieckiego urzędu pracy BERUFENET ${ }^{15}$ zawiera informacje o zawodzie, branżach, wymaganiach, wynagrodzeniach oraz filmy o zawodach. Informacje podawane są również z perspektywy uczniów. Platforma ta jest ważna w społecznym odbiorze z uwagi na aktualizacje i obiektywizm. Główna orientacja zawodowa odbywa się jednak w szkołach przy wsparciu zainteresowanych pracodawców, Izb Rzemieślniczych i Izb Przemysłowo-Handlowych. Poradnictwo stanowi integralny system nauczania i wychowania w Niemczech, przybierając różne formy na wszystkich szczeblach kształcenia (Piorunek, 2016, s. 6).

Aktualną potrzebą jest zwiększenie efektywności orientacji zawodowej dla uczniów gimnazjów. O ile w szkołach głównych i realnych z zasady ukierunkowuje się na edukację zawodową, o tyle nauka w gimnazjach ukierunkowana jest na kontynuację na szczeblu akademickim. O systemie dualnym gimnazjaliści wiedzą niewiele. Zatem system poradnictwa zawodowego i orientacji zawodowej jest bardziej rozbudowany w dwóch pierwszych typach szkół. Tu pracodawcy potencjał widzą w rozbudowaniu w gimnazjach, dotąd jednostronnej orientacji akademickiej, o aspekty zawodowe. Szczególnie jest to istotne z uwagi na rosnącą liczbę studentów przerywających studia i trafiających do systemu w drugim wyborze. Wielu z tych uczniów dualnego systemu edukacji na szczeblu wyższym odnajduje się w odmiennym systemie nauki. Wcześniejsza orientacja zawodowa z pewnością zaoszczędziłaby czas, energię i koszty. Zrozumiano, że należy pozwolić uczniom zbudować lepszą, proaktywną orientację zawodową. Jest to istotne, bo wiadomo, że 60000 byłych studentów akademickich w roku 2018 po przerwaniu studiów przeszło do systemu dualnego na poziomie wyższym (U. Friedrich, 2019, s. 12). Tak więc zakres problematyki i potencjał konieczności zmian jest duży. Z tego względu rynek pracy zaczyna traktować tych kandydatów jako ważną grupę dla przedsiębiorstw. Przykładem jest nowo powołana inicjatywa „Z doświadczeniem do sukcesu"16.

Ważne w tym procesie jest systemowe podejście pracodawców do instytucji praktyk dla gimnazjalistów (BOGY) ${ }^{17}$. Ta obowiązkowa dla ucznia orientacja zawodowa w przedsiębiorstwie w klasie 10 daje obu stronom szansę na rozpoznanie możliwości, predyspozycji i wyobrażeń o pracy w określonych zawodach. Dla ucznia to możliwość sprawdzenia się w konkretnych sytuacjach w czasie prób pra-

15 Szerzej na ten temat zob. https://tiny.pl/7w9wj [dostęp: 29.03.2020].

16 Szerzej na ten temat zob. https://www.ihk.de/mit_praxis_zum_erfolg [dostęp: 29.03.2020].

17 BOGY - Berufs- und Studienorientierung am Gymnasium; szerzej na ten temat zob. http:// bo-bw.de/,Lde/Startseite [dostęp: 12.04.2020]. 
cy. Dla pracodawcy jest to szansa na alternatywny, prowadzony z wyprzedzeniem czasu proces obsadzania miejsc nauki. Dla obu stron konstruktywna konfrontacja wyobrażeń o zawodzie z realnymi wymaganiami rynku pracy. Co istotne, konfrontacja ta nie pozostawia iluzji, a zatem neutralizuje ewentualne rozczarowania w przyszłości dla dualnych partnerów. Analogiczne praktyki prowadzone na szczeblach szkoły głównej (OIB) i realnej (BORS) są bardziej rozbudowane i osadzone W rzeczywistości rynku pracy ${ }^{18}$. W tym zakresie szkoły prowadzą współpracę z podmiotami gospodarczymi i kierują uczniów „na praktyki” wcześniej (klasy 8 i 9) oraz na dłużej (dwa tygodnie). Poza obowiązkową orientacją zawodową w przedsiębiorstwach prowadzone są przez nauczycieli i doradców informacje zawodowe w szkołach. Uczniowie korzystają również z fakultatywnych warsztatów zawodowych lub mogą ponowić praktykę orientacyjną w czasie ferii.

Współpraca niemieckich szkół i pracodawców w zakresie promowania orientacji zawodowej nabiera nowych kształtów. W odróżnieniu do lat ubiegłych zmienia się zakres aktywności pracodawców w szkołach. Pomysłowe okazało się wysyłanie do szkół „ambasadorów” dualnego kształcenia. Są nimi obecni adepci zawodu. Nikt lepiej nie uwiarygodni młodszym kolegom swojej pasji zawodowej, jak uczeń mówiący do innych uczniów o blaskach i cieniach własnych doświadczeń w zawodzie. W badanym przez Izbę Przemysłowo-Handlową roku 2018 aż 19\% pracodawców praktykowało formę orientacji „od ucznia dla ucznia”. Warto dodać, że przedsiębiorcy wykazują się kreatywnością w koncepcjach współpracy ze szkołą. Młodzi „ambasadorzy” systemu dualnego są szkoleni i prowadzą warsztaty o danym zawodzie. W rzeczywistości digitalnej, w której żyje młodzież, ta forma kontaktu jest kontynuowana w mediach społecznościowych. Wpływa to na pozytywny odbiór systemu i zainteresowanie kształceniem zawodowym. Forma ta z uwagi na autentyczność efektywniej wspiera proces wzbudzania i rozpoznawania zainteresowań zawodowych młodszej generacji.

\section{PARTNERSTWO W KSZTALCENIU DUALNYM NA RZECZ TOŻSAMOŚCI ZAWODOWEJ}

Korelacja nauki teorii w szkole z nauką zawodu w miejscu pracy jest wyznacznikiem dualnego kształcenia. Sądzę, że potrzeba kooperacji tych sfer niemieckiej edukacji jeszcze nigdy nie była tak silna jak obecnie. Współpraca w kontekście

18 OIB - Orientierung im Betrieb, BORS - Berufsorientierung in der Realschule; szerzej na ten temat zob. https://tiny.pl/7w9dj [dostęp: 12.04.2020]. 
edukacji zawodowej 4.0, digitalizacji, potrzeby kształtowania kompetencji niezbędnych w zmieniających się technologiach i procesach organizacji pracy, staje się wyzwaniem o niespotykanym dotąd zakresie. Zdaniem Boscha system edukacji dualnej musi - jak nigdy dotąd - wykazać się szybkim tempem zmian dostosowanych do procesów pracy, gdyż jego podstawą są treści specyficznych obszarów zawodowych (Bosch, 2018, s. 15).

Obecnie prawie jedna trzecia niemieckich pracodawców postuluje ściślejszą współpracę szkół z przedsiębiorstwami w zakresie dostosowania tempa postępu technologicznego do nauczania teoretycznego. W odróżnieniu od lat ubiegłych, gdzie zdecydowana większość partnerów deklarowała zadowolenie ze współpracy, aktualna potrzeba działania na rzecz ścisłej wymiany zdaje się pilna (U. Friedrich, 2019, s. 12). Dotyczy to obszarów, w których procesy w przedsiębiorstwach zmieniają się o wiele szybciej niż treści nauczane w szkołach czy modernizacja szkolnej bazy technicznej. Aktualnie - zgodnie z badaniem Izby Przemysłowo-Handlowej - dominujące branże to technologie informatyczne, media i handel.

Wprowadzenie na początku lat 90. XX wieku do produkcji „lean-production” wywołało zmiany w unowocześnianiu zawodów w systemie dualnym ${ }^{19}$. Poprzez wprowadzenie nowych technologii technik informatycznych w roku 1997 powstały nowe zawody IT w zakresie produkcji i usług. Przyszli wykwalifikowani pracownicy branży IT uczą się w systemie dualnym również niektórych czynności, które w innych krajach UE zastrzeżone są dla kształcenia akademickiego (Bosch, 2018, s. 16). To z kolei determinuje unowocześnianie bazy w szkołach i udostępnianie nauczycielom doskonalenia zawodowego adekwatnego do postępu zmian. Odpowiedzią na rosnące tempo zmian jest opis ram programowych zawodów koncentrujący się na wspólnych kluczowych czynnościach kwalifikacyjnych danego zawodu. Uznano, że wykorzystywane dotąd technologie są nie tylko zmienne w czasie, ale zróżnicowane w sektorach gospodarki. Szczególnie ważna i cenna staje się w niemieckim systemie współpraca szkół z przedsiębiorstwami małymi i średnimi. Te zakłady nie dysponują tak prężnym zapleczem zarządzania zasobami ludzkimi, jak większe firmy. Współpraca ta jest ważna z uwagi na przepływ komunikacji i wymianę doświadczeń między nauczycielami zawodu a mistrzami praktycznej nauki zawodu w przedsiębiorstwie. Partnerstwo w obliczu zmian technologicznych jest nieodzowne. W Niemczech działania inicjowane są często proaktywnie, niezależnie od instytucjonalnych powinności podmiotów. Inspirującym przykładem są ośrodki szkoleniowe, które dysponują wyposażeniem technicznym i są wsparciem dla obu partnerów systemu dualnego. Ośrodki te

19 Lean manufacturing (pol. szczupła produkcja): koncepcja zarządzania procesem produkcji. 
oferują sprzęt dla uczniów, prowadzą kursy doskonalące dla nauczycieli zawodu. To partnerstwo w obliczu zmian technologicznych, ograniczonych możliwości adaptacyjnych placówek szkolnych i mniejszych przedsiębiorstw jest cenne. W ten sposób szkoły zacieśniają współpracę w zakresie realizowanego materiału tak, by uczeń w czasie nauki w miejscu pracy dysponował przygotowaniem teoretycznym, zgodnym z aktualnym poziomem technologicznym.

Siła partnerstwa pomiędzy szkołą a pracodawcą w systemie dualnym sprawdza się w przygotowaniu uczniów w zakresie kluczowych kompetencji społecznych. Kształtowanie koniecznych i pożądanych kompetencji społecznych - zdaniem Kwiatkowskiego - pozwala na refleksję dotyczącą własnej tożsamości zawodowej (Kwiatkowski, 2016, s. 35). Ona jest warunkiem współpracy i odpowiedzialności. W związku z postępem technologicznym zmieniają się procesy pracy, a z tym sprzężone sposoby nauczania zawodu i kształtowania kompetencji. Celem początkowej fazy nauczania jest rozwój kluczowych kompetencji, wspólnych dla tej samej grupy zawodów. Praktyką zatem jest nauczanie uczniów w zespołach o tym samym rdzeniu danej profesji. Punkt ciężkości nauczania przesuwa się z nauczania specjalistycznego na nauczanie w zespołach uczniów o podobnych zawodach. W związku ze zmianami społeczno-gospodarczymi znaczenia nabiera zorientowanie na obsługę klienta i usługi. Uczenie się w obecnym dualnym systemie niemieckim wypiera socjalizację przyszłych adeptów zawodu z hierarchicznych i funkcjonalnych form organizacji pracy i tradycyjnego myślenia o zakresie wykonywanych zadań. Procesy socjalizacyjne zmierzają w stronę samodzielnej organizacji w elastycznych formach pracy (Bosch, 2018, s. 18).

W tym kontekście szkoły i pracodawcy zmuszeni są zacieśniać wymianę doświadczeń, prowadzić lekcje i szkolenia w taki sposób, by korelować tematykę z zakresem i czasem realizacji. Doskonalenie uczniów w wewnętrznych akademiach pracodawców i taktyka warsztatów kompetencyjnych w szkołach - są godną uwagi siłą płynącą z partnerstwa na rzecz rozwoju tożsamości zawodowej. Inspirujące są praktyki stosowane w średnich przedsiębiorstwach, zwłaszcza rodzinnych. Ta forma kształcenia i współpracy podkreśla silną motywację partnerów. Zaangażowanie przedsiębiorców ma źródło w ekonomicznych uwarunkowaniach, „zapewnienia sobie kadr o wysokich kwalifikacjach, lepszej selekcji kandydatów dzięki kilkuletniej obserwacji, zmniejszenia kosztów rekrutacji i fluktuacji kadr” (Kabaj, 2012, s. 89). Szkoły zyskują wsparcie osadzone w realiach gospodarczych i możliwość synchronizacji treści nauczania. Na szczeblu lokalnym krystalizują się konkretne formy współpracy na rzecz danej społeczności.

Nowa forma kooperacji szkół z przedsiębiorstwami wyodrębniła się mocno w ostatnich pięciu latach wraz z napływem fal uchodźców z krajów Trzeciego 
Świata. Szkoła stała się miejscem integrującym migrantów, kształtującym kompetencje językowe, przygotowującym tych uczniów do egzaminów zawodowych. W niej kształtowane są kompetencje kluczowe dla funkcjonowania w społeczności europejskiej. To w szkole następuje integracja społeczna uczniów. Zmiany w aspekcie wielokulturowości w strukturach systemu dualnego nastąpiły nie tylko w postaci uruchomienia programów języka niemieckiego, szkoleń integracyjnych lub adaptacji już istniejących programów do specyficznych potrzeb tych uczniów. Zmienił się obraz partnerów dualnych i sposobu myślenia. Relacja nauczyciel - uczeń, mistrz - uczeń nabrała nowego wymiaru. To nie tylko osoba ucząca zawodu, ale człowiek, który wprowadza również w tło kulturalne i przekazuje inne, nowe wartości migrantom. Nauczyciel i mistrz zawodu staje współcześnie przed wyzwaniem integrowania uczniów o odmiennym pochodzeniu, wdrażania w arkana profesji z większą niż kiedykolwiek cierpliwością, łagodzenia napięć międzykulturowych. Migranci są na stałe wpisani w obraz społeczeństwa niemieckiego. Tym samym fala migracji 2015 roku otworzyła szanse dla systemu dualnego. Integracja tych uczniów jest trudna i wydłużona w czasie. Motywacja wewnętrzna tych ludzi do zdobycia zawodu jest przy wielu trudnościach jednak szczególnie silna. To trudna droga dla wszystkich stron. W tym aspekcie wymiana między szkołą a pracodawcą jako partnerami dualnymi jest intensywna i musi być coraz silniejsza.

\section{PODSUMOWANIE}

Dynamiczne zmiany naszych czasów zmuszają do zastanowienia się nad efektywnością nauczania zawodowego w systemie dualnym. Należy przewidzieć, że uczniowie teraz kształceni zawodowo będą wykorzystywać swoje kompetencje w świecie, którego jeszcze nie znamy. W przypadku migrantów jest to jeszcze większe wyzwanie. Dlatego poszukiwanie nowych rozwiązań jest koniecznością. W kontekście aktualnych zmian ukierunkowanie edukacji zawodowej zarówno na przybyszów z krajów Trzeciego Świata, jak i nauki zawodu 4.0 jest szczególnym wyzwaniem w Niemczech. Odkrywanie szans tam, gdzie inni widzą bariery, jest jednym ze znamion tego systemu opartego o siłę dualną partnerów: zakładów pracy i szkół.

Jak wynika z przedstawionych tu danych, system nauczania dualnego w Niemczech nabiera wyjątkowego charakteru. Staje się on podstawą dla działań szkolnictwa, przedsiębiorstw, izb przemysłowo-handlowych, urzędów pracy i polityków. Traktowany jest priorytetowo, gdyż niesie korzyści dla dalszego rozwoju niemiec- 
kiej gospodarki, i między innymi dlatego cieszy się społecznym poparciem. „(...) Kształcenie zawodowe przyczynia się do konkurencyjności naszych gospodarek narodowych zarówno dziś, jak i w przyszłości (...)” (Nikel, 2017). Wszelkim działaniom na tym polu towarzyszy troska o kształt nowego wielokulturowego społeczeństwa, w którym złagodzone zostaną konflikty interesów, a podtrzymane sprawdzone od dawna hierarchie wartości. Niemiecki system dualny ma być busolą ku nowoczesności, otwierać ścieżki ku nowym technologiom i współczesnym osiągnięciom nauki. Jednocześnie zwraca się ku człowiekowi i uwzględniając jego potrzeby, wprowadza w arkana istotnych życiowych zadań, przedsięwzięć i projektów. Selekcja, jaka dokonuje się w tym systemie, jest nieunikniona, a jednak czyni się wszystko, by pozyskać jak najwięcej kandydatów do nauki dualnej. Poczynaniom tym towarzyszy nie tylko czysty utylitaryzm, ale humanitarna troska o młode pokolenie. Zaangażowanie wielu instytucji dowodzi, że sprawa kształcenia zawodowego obejmuje pokaźne obszary działań i stała się kluczowym zadaniem.

Zgodnie z nową wizją edukacji Komisji Europejskiej opracowuje się programy i projekty, by system sprawnie funkcjonował, i to w interesie wszystkich zaangażowanych podmiotów (Komisja Europejska, 2012). Nowe kierunki pobudzania wzrostu gospodarki, zainicjowane również komunikatem w sprawie bezrobocia osób młodych, znajdują oddźwięk w aktualnych dyskusjach o reformie kształcenia zawodowego w Polsce (Symela, 2016, s. 10; Komisja Europejska, 2013). Nasi zachodni sąsiedzi za Odrą wypracowali wysoce pragmatyczny system kształcenia zawodowego, który podlega wpływom innowacji i zmianom. W efekcie korzyści z niego płynące zauważalne są teraz, a jednocześnie budzą optymistyczne perspektywy. System korzysta z aktualnych badań i doświadczeń, ale nastawiony jest na dalsze udoskonalenia. Obecne wyzwania nie są łatwe, ale dają szansę na rozwój nowych rozwiązań i wykorzystanie w tym zakresie wszelkich możliwości. Obserwując ten proces w Niemczech i wdrażania polskiej reformy edukacji zawodowej, warto odnieść się do sprawdzonych doświadczeń naszych sąsiadów, sposobu podejścia do nowych problemów, postrzegania cudzoziemców w procesie kształcenia i roli dualnych partnerów w obliczu dynamiki zmian współczesnej gospodarki i społeczeństwa.

\section{Bibliografia}

Bildung und Kultur. Berufliche Bildung. 2018. (2019). Fachserie 11, Reihe 3. Wiesbaden: Statistisches Bundesamt (Destatis).

Bosch, G. (2018). Das duale System der Berufsbildung in Deutschland. Paris: Ifri. 
Bundesagentur für Arbeit, Statistik. Ausbildungsmarkt. (2019). Die aktuellen Entwicklungen im Berichtsjahr 2018/2019 in Kürze - Stand: September 2019. Pobrane z: https:// tiny.pl/7w996.

Chatzichristou, S., Ulicna, D., Murphy, I., Curth, A., (2014). Dualny System kształcenia: rozwiqzanie na trudne czasy. Bruksela: ICF International.

Clupepper, P.D., Finegold, D., (1999). The German Skills Machine: Sustaining Comparative Advantage in a Global Economy. New York-Oxford: Berghahn Books.

Friedrich, M. (red.) (2019). Datenreport zum Berufsbildungsbericht 2019, Informationen und Analysen zur Entwicklung der beruflichen Bildung. Bonn: Bundesinstitut für Berufsbildung.

Friedrich, U. (red.) (2019). DIHK Ausbildung 2019. Ergebnisse einer DIHK-Online-Unternehmensbefragung. Berlin-Brüssel: DIHK - Bereich Ausbildung.

Fritsch, R. von. (2013). Przemówienie Ambasadora Niemiec w Polsce Rüdigera Freiherra von Fritscha na konferencji: Kształcenie zawodowe w systemie dualnym inwestycja w rozwój gospodarczy. Pobrane z: http://konferencje.frse.org.pl/img/default/Mfile/1071/file.pdf.

Granato, M., Milde, B., Urlich J.G. (2018). Passungsprobleme auf dem Ausbildungsmarkt. Eine vertiefende Analyse für Nordrhein-Westfalen. Düsseldorf: Forschungsinstitut für gesellschaftliche Weiterentwicklung e.V.

Kabaj, M. (2016). Główne bariery wdrożenia dualnego systemu kształcenia zawodowego w Polsce. Polityka Społeczna, 9.

Kabaj, M. (2012). Wpływ systemów kształcenia zawodowego na zatrudnienie i bezrobocie młodzieży. Warszawa: IPiSS.

Kraus, P., Schönwälder, K. (2006). Multiculturalism in Germany: Rhetoric, Scattered Experiments and Future Chances. W: K. Banting, W. Kymlicka (red.), Multiculturalism and the Welfare State: Recognition and Redistribution in Contemporary Democracies. Oxford: Oxford University Press.

Kraus, P., Weitz, H. (2020). Bauwirtschaft in Zahlenbild 2019. Berlin: Hauptverband der Deutschen Bauindustrie e.V.

Kwiatkowski, S.M. (2016). Kompetencje społeczne pracowników - kontekst edukacyjny. Polityka Społeczna, 9.

Kwiatkowski, S.T., Nowosad, I. (2018). System kształcenia i doskonalenia nauczycieli w Singapurze. Między utopijną wizją a rzeczywistością. Studia Edukacyjne, 47.

Nikel, R. (2017). Przemówienie Ambasadora Niemiec w Polsce Rolfa Nikela na konferencji: Rynek pracy wyzwaniem, kształcenia zawodowe szansq. Pobrane z: https:// tiny.pl/7w9dl.

Piorunek, M. (2016). Poradnictwo zawodowe w kontekście potrzeb uczniów szkolnictwa zawodowego. Polityka Społeczna, 9.

Rattansi, A. (2011). Multiculturalism: A Very Short Introduction. Oxford: Oxford University Press.

Sponholz, D., Urich, J.G. (2019). Passungsprobleme beim Zugang in die duale Berufsausbildung. W: Sonderpädagogische Förderung heute (2. Beiheft: Inklusive Berufsorientierung und berufliche Bildung - aktuelle Entwicklungen m deutschsprachigen Raum). [praca niepublikowana]. 
Statistisches Bundesamt (Destatis) (2019). Ausbildungsverträge, Bestandene Abschlussprüfngen. Wiesbaden.

Statistisches Bundesamt (Destatis) (2019). Bildung und Kultur. Berufliche Bildung. 2018. Wiesbaden.

Stępnikowski, A. (2016). Kształcenie zawodowe - wyzwania i trendy rozwojowe na świecie. Polityka Społeczna, 9.

Stratmann, K. (1993). Die gewerbliche Lehrlingserziehung in Deutschland. Modernisierungsgeschichte der betrieblichen Berufsbildung. Band 1: Berufserziehung in der städtischen Gesellschaft (1648-1806). Frankfurt.

Symela, K. (2016). Rozwój dualnego systemu kształcenia w Polskiej przestrzeni szkolnictwa zawodowego i rynku pracy. Polityka Społeczna, 9.

Wegner, J. (red.) (2019). Mehr Ausländer fangen eine Ausbildung in Deutschland an. Hamburg: ZEIT Arbeit.

\section{Akty normatywne}

European Commision (1994). Growth, Competitiveness, Employment. Brussels.

Gesetz über den Aufenthalt, die Erwerbsfähigkeit und die Integration von Ausländern im Bundesgebiet, Art. 60c. (2020). Pobrane z: http://www.gesetze-im-internet.de/ aufenthg_2004/.

Komisja Europejska. (2012). Komunikat Komisji do Parlamentu Europejskiego, Rady, Europejskiego Komitetu Ekonomiczno-Społecznego i Komunikatu Regionów Nowe podejście do edukacji: Inwestowanie w umiejętności na rzecz lepszych efektów społeczno-dozorczych, COM(2012) 669 final. Strasburg.

Komisja Europejska. (2013). Komunikat Komisji do Parlamentu Europejskiego, Rady, Europejskiego Komitetu Ekonomiczno-Społecznego i Komunikatu Regionów Pracując wspólnie na rzecz młodych Europejczyków - Wezwanie do działania w sprawie bezrobocia osób młodych, (COM(2012) 447). Bruksela. 